\title{
Someone else's chain, someone else's road: U.S. military strategy, China's Belt and Road Initiative, and island agency in the Pacific
}

\author{
Sasha Davis \\ Keene State College, USA \\ Sasha.davis@keene.edu \\ Lexi A. Munger \\ Keene State College, USA \\ Lexi.Munger@ksc.keene.edu \\ Hannah J. Legacy \\ Keene State College, USA \\ Hannah.Legacy@gmail.com
}

\begin{abstract}
The islands of the western Pacific have increasingly been portrayed by policymakers, military strategists, journalists, and scholars as places caught between a rising China and traditional powers such as the United States and their allies. In this article, however, we aim to challenge the geopolitical view of islands as 'falling' into the sphere of influence of one power or another. Specifically, we use an approach informed by assemblage theory to highlight the ways that islands in the Pacific simultaneously engage with multiple powers and their associated political, economic, and social influences. To ground our argument, we discuss two 'great power' schemes that aim to bring islands in the region into specific relational configurations: U.S. 'littoral defense lines' and China's Belt Road Initiative. We also include a brief case study of Chinese tourism investment in Yap Island (Wa'ab) in the Federated States of Micronesia (which is a state in 'free association' with the U.S.). Through these examples, we show how influence in the island Pacific is not a zero-sum game between foreign powers vying for hegemony. Instead, from an island perspective, residents and policymakers are attempting to weave together and navigate multiple foreign influences in ways that frustrate colonial and neocolonial logics of international relations.
\end{abstract}

Keywords: assemblage, Belt and Road Initiative, China, geopolitics, islands, 21st Century Maritime Silk Road, military, Micronesia, Yap

https://doi.org/10.24043/isj.104 • Received April 2019, accepted September 2019

(C) 2019-Institute of Island Studies, University of Prince Edward Island, Canada. 


\section{Introduction}

The ambitions and plans of distant powers have long affected islands in the Pacific. While one only needs to look at the extensive histories of various colonial projects to see the effects of the political, economic, and military schemes of continental states; the contemporary era is little different. As we will detail in this paper, ever since World War II the islands of the western Pacific have been critical nodes in a military network designed to provide national security to the U.S., Japan, New Zealand, and Australia (Davis, 2015; Immerwahr, 2019; Kearns \& Collins, 2016; Powles, 2015; Shigematsu \& Camacho, 2010; Watson \& Pandey, 2015). In recent years, however, China has increased investment, aid, and diplomatic initiatives in the region (Bohane, 2018a; Wesley-Smith, 2013; Yang, 2011). As China's economy has grown and the Chinese government has increased its level of international engagement, Chinese influence in the Pacific islands - and the accompanying concerns and backlash — has risen as well. This phenomenon is, of course, not limited to islands in the Pacific (Blanchard, 2017, 2018; Blanchard \& Flint, 2017; Erickson \& Wuthnow, 2016; Grydehøj et al, 2017; McElroy \& Bai, 2008; Nolan, 2013, 2015). The islands of the Pacific, however, are a noteworthy realm for examining the implications of China's growing influence since they are also the places where the U.S. (and allied states) have intense military and (colonial) political arrangements that are explicitly designed to 'contain' China (Bergerson, 2016; Davis, 2015; Lutz, 2009; Vine, 2015).

In particular, the island Pacific has been incorporated into China's '21st Century Maritime Silk Road' project, which is part of its larger Belt and Road Initiative (BRI). The BRI, which also goes by the label 'One Belt, One Road', includes land-based infrastructures across Asia (the 'Belt') as well as oceanic transportation networks (a marine-oriented 'Road') in the Pacific, Indian, and Arctic Oceans (Suokas, 2017; National Development and Reform Commission, 2015; National Development and Reform Commission \& State Oceanic Administration, 2017). The BRI envisions the development of infrastructure projects around the world in an effort to create investment opportunities for Chinese banks and firms, as well as to intensify Chinaoriented trade (Mathews, 2019). These new projects imagine creating new assemblages of connection between islands across the western Pacific which challenge older constellations of geopolitical order orchestrated by the U.S., Australia, New Zealand, and others. How, though, have residents and policymakers in the island Pacific been navigating these shifting political and economic currents? Furthermore, as people on these islands make decisions within this shifting milieu, how do their decisions 'scale-up' and affect larger global economic circulations and security architectures?

Recently, many commentators, security experts, and politicians have represented the island Pacific as a contested realm where an assertive China is challenging U.S. dominance as well as the traditional leadership roles of the Australian, Japanese, and New Zealand governments (Bergerson, 2016; Davis 2015; Matelski, 2016; Meick, Ker, \& Chan, 2018; Yang, 2011). Many of these analyses revolve around the 'China threat' narrative and are clearly written from the point-of-view of traditional Western powers who examine Chinese influence in islands through the lens of the potential threats to Western security doctrines. Some of the more alarmist representations speak of the U.S. "losing the Pacific" (Bohane, 2018a) or "America's Micronesia Problem" (Matelski, 2016). Others see an eminent Chinese military use for any Chinese-made infrastructure in the island Pacific. A case in point is the wharf built in 2018 in Espiritu Santo, 
Vanuatu by the Shanghai Construction Group Company. Shortly after its construction, Australian politicians and observers noted that such as a dock could have future military uses which could threaten Australia. One Australia-based journalist highlighted the fact that the 360meter-long dock could "take in some of the biggest warships on earth" (Wroe, 2018).

Not all authors, however, have been so fearful of Chinese influence in the Pacific. Some authors take a more ambivalent stance, but still see the 'disruption' Chinese power causes in political and economic arrangements that have been stable since the end of the World War II (Nolan, 2013, 2015; Wesley-Smith, 2013; Yang, 2011). The recognition that islands have long been crucial locales from which global balances of power have been forged and contested underpins many of these concerns (Benítez-Rojo, 1997; Davis, 2015; Nolan, 2013). Despite traditional Western views of islands as spaces of disconnection and separation from continental processes (Shell, 2014), Indigenous scholars and island studies researchers have long emphasized the ways in which individual islands are actually highly connected spaces that are not only deeply influenced by circulations with continents, other islands, and the marine environments in which they are situated-but are also sites which affect those circulations (Baldacchino, 2006; Bevacqua, 2017; DeLoughrey, 2007; Diaz, 2011; Grydehøj \& Casagrande, 2019; Hau'ofa, 1994; Hayward, 2012; Na'puti, 2019; Na'puti \& Bevacqua, 2015; Pugh, 2013, 2016, 2018; Steinberg \& Peters, 2019; Stratford et al, 2011). Island studies scholars have emphasized that this connectivity influences not only political processes, but almost all aspects of island environments and societies. Much of the research in island studies today takes a relational view of islands that emphasizes that island societies are quite literally constructed through connections to other places and the oceanic environments around them (Chandler \& Pugh, 2019; Davis, 2017; Grydehøj, Nadarajah, \& Markussen, 2019; Hayward, 2012; Hong, 2017, 2019; Pugh, 2013, 2016, 2018; Stratford et al, 2011). In sum, no island is an 'island' in the Western metaphorical sense. Instead islands come to be, and are sustained-physically, ecologically, and sociallythrough the relating of various elements, processes, people, cultures, economic circulations, and political apparatuses.

Despite the prevalence in island studies of these more nuanced perspectives that view influence in islands as a multi-valanced hybrid 'dance' of human and environmental processes, many powerful actors still represent the region in more black-and-white terms where influence over an island is a zero-sum game and where an increase in influence by one external power results in its loss by another. More simplistic still, some look for a 'line' in the island Pacific where one external power's 'sphere of influence' begins and where another one ends (Bergerson, 2016; Meick, Ker, \& Chan, 2018; Yang et al, 2018). One explicit example of this sphere of influence approach is provided by Lyle Goldstein, director of the China Maritime Studies Institute at the U.S. Naval War College, who notes of the Micronesian islands of the western Pacific, "It is around these islands that the line of spheres of influence between the [U.S. and China] are being drawn [...] The question is where does the line switch?" (qtd. in Tobin, 2019, p.1).

As we will elaborate in this paper, we believe the perspective that views islands as wholly falling into one sphere of influence or the other-and then frets over "where does the line switch'-is both analytically inaccurate and overlooks the agency of island residents to engage in multiple economic, political, and social networks. We find the contemporary debates that center around a 'rising China' and 'waning West' to be stuck in an anachronistic mode of dualistic logic where 'influence' in island spaces is portrayed as an either/or, zero-sum game of imperial 
rivalry amongst external powers. Rather than representing the islands of the Pacific as 'falling' into either the orbit of the U.S. and its allies or the Chinese orbit, we believe it is much more analytically responsible to question these dichotomies and to instead examine how the recent increased Chinese investment, economic integration, and political attention articulates with older projects of political and social influence over islands. Furthermore, how do island citizens and policymakers navigate the threats and opportunities produced by these shifting foreign influences?

To counter this popular view of islands as pawns in a geopolitical chess game between larger powers, in this article we examine two major contemporary projects that attempt to arrange islands in the Pacific into larger assemblages: the U.S. 'island chain' security strategy, and China's BRI, which represents islands as potential nodes along routes of international investment and trade. We also discuss a case study of Yap Island (Wa'ab) in the Federated States of Micronesia (FSM). While Yap is somewhat peripheral to both the BRI and U.S. military activity, it is a location where the logics of the two larger projects of U.S. island-oriented military security and the development of Chinese financed megaprojects occur on the same island. There are, of course, many other processes that have large impacts on life in the island Pacific, such as Australian aid programs, New Zealand free association connections, continued French colonial relationships, and regional initiatives through the Pacific Islands Forum; but we focus on U.S. militarization and Chinese economic investment to give illustrative, but not exhaustive, examples of foreign-designed schemes affecting islands in the region. The information for this study comes from a review of academic sources, government documents, and news articles; as well as from field research and interviews conducted in Yap, Guam, the Northern Mariana Islands, Palau, and China between 2016 and 2018.

\section{Island assemblages}

In this paper we examine the political, economic, and social influences of grand schemes for islands - like the U.S. defense network and the BRI - through the lens of assemblage theory. This approach emphasizes that islands, like all entities, are constructed through their relations and connections to other entities and places (Anderson, Keanes, McFarlane, \& Swanton, 2012; Davis, 2017; DeLanda, 2006; Deleuze, 1988; Deleuze \& Guattari, 1987; Dewsbury, 2011; Dittmer, 2014; Featherstone, 2011; Legg, 2011; McFarlane, 2009; Müller, 2015; Pugh, 2018). In other words, no place has a particular autonomous 'essence' or internally constructed fundamental 'nature'. Instead, all places (including islands) are reproduced within 'assemblages' which are defined as webs of interaction and material exchanges with other people, ideas, and places (Deleuze, 1998). While discussions of assemblage theory can be quite dense and complex, our goal is not to perform a theoretical exercise or to complicate analyses. On the contrary, our aim is to show a different way to conceptualize influence in the region which can be used to make more sense of on-the-ground realities. In this spirit, while there are many aspects of the assemblage theory approach that are useful for island studies research, in this paper we have chosen to select a few specific insights that we feel are critical for contextualizing our discussion.

The first point we want to emphasize is that when islands get connected together into particular groupings and functional inter-relationships, the resultant groupings are not 'natural' or inevitable, but rather are an effect of power. Islands in the ocean, like stars in the sky, are not intrinsically connected to others. This, however, has not stopped anyone from imagining them as 
being connected together in particular ways. Just as sky gazers have looked upward from Greece, Hawai'i, North America, and China and seen different constellations among the same stars, different actors have looked at maps of the islands across the Pacific and imagined different ways to group them together and construct linkages between them. A crucial difference between the stars and islands, however, is that throughout history people have managed to find ways to actively bring islands into closer relation with each other or find ways to artificially distance some islands from others.

This brings us to the second insight from assemblage theory that we wish to emphasize. Namely, assemblages are made real through material infrastructures that aim to orient islands toward particular functions and toward particular places. U.S. officials may see the islands of the Pacific as a constellation of military outposts, and Chinese planners may see them as nodes along a Maritime Silk Road, but they do not function as either without the construction of actual runways, ports, and other facilities (Chua, Danyluk, Cowen, \& Khalili, 2018; Cowen, 2014). These infrastructures may have the ability to carry out multiple functions (as discussed below), but their builders frequently design them to have interoperability with other nodes in their assemblage in such a way as to channel and direct interaction into specific 'technological zones' (Barry, 2006; Dittmer, 2018). Put simply, U.S. planners design and build infrastructure in the island Pacific that matches the standards used by their military and commercial enterprises, which serve the goals of U.S. policy, create financial opportunities for U.S. firms, and make transportation between these islands and the U.S. easier, faster, and cheaper. Meanwhile, other powers (including China and its plans with the BRI), aim to construct specific kinds of infrastructure that better orient islands towards their homelands.

These practices of changing the 'topological space' of the Pacific (i.e. bringing islands into tighter, or more distant, relations) have had dramatic effects on local landscapes and societies as well as on regional and global patterns of politics and economy (Allen, 2011, 2016). The borders across the Pacific left by imperial rivalries are ample evidence of this: whether through infrastructures that bring Tahiti functionally closer to Paris, or Guam (Guåhan) closer to the U.S.; or through the political separations of nearby Samoa from American Samoa, Guam from Rota, or Bougainville from the Solomon Islands. We argue that both the U.S. project of island chain defense and China's BRI are attempts to construct particular geographies of connection, disconnection, interoperability, and function across the region that aim to 'direct' islands toward particular foreign powers.

The third theoretical point we aim to make in this paper, however, is that while these constellations of material infrastructures aim to orient islands in particular directions, these facilities can be redesigned or redirected toward other places and purposes. Therefore, any assemblage of islands is unstable and can be altered, shifted, or abolished. As the theorist Manuel DeLanda (2006) posited-and many geographers have emphasized (Anderson, Keanes, McFarlane, \& Swanton, 2012; Dewsbury, 2011; Featherstone, 2011)—geographical assemblages are held together by "relations of exteriority." This means that components of any assemblage are contingently brought together. Theorists are at pains to emphasize that elements in any particular assemblage have capacities to serve in that assemblage, but could very well detach and be connected to other ones. If we view an island like Yap through this lens, we can see how it has articulated with, and then disengaged from, all sorts of larger assemblages over time. Yap has been connected to Palau in assemblages of migration and trade for centuries (Yap's famous 'stone 
money' for instance comes from Palau) (Lingenfelter, 1975). It has also had a revolving door of colonial administrations. First colonized by the Spanish, Yap and the surrounding Caroline Islands were then sold to the German Empire in 1899, then granted as a mandate to the Japanese government in 1923, and then ruled by the U.S. as part of the Trust Territory of the Pacific Islands from the end of the World War II up until its formal independence in free association with the U.S. in 1986. While these switches occurred, the airfields, ports, and colonial government facilities have merely been reused and repurposed by each successive administration. The point is that Yap is not intrinsically part of an assemblage with Palau, Spain, Germany, Japan, the U.S., or even the rest of the FSM (or, as we shall discuss, the U.S.'s 'defensive line' in the Pacific or a new Maritime Silk Road). It has the capacity to be involved in these various assemblages depending on how it is brought into relation with other places. Islands like Yap therefore can be conceptualized as being in a 'liminal' state, both spatially and temporally: a place between imperial projects, between spheres of influence, between the heyday of U.S. hegemony and the ascendency of China. They can be seen as places "existing on the edge of one configuration and therefore on the precipice of rapid transformation" (McConnell \& Dittmer, 2018, p.144).

While the history of colonial hand-offs we sketched above might make it appear that incorporation into larger assemblages is an either/or affair (an island is part of this empire or that) and that only powerful external actors have the agency to determine how islands articulate with them, we actually contest both of these assertions. The fourth point from assemblage theory we want to emphasize is that any island can be part of multiple assemblages at the same time. Interconnection with one assemblage does not preclude simultaneous connections with others. Given the expansive definition of assemblages offered above, it is clear that most islands are part of multiple assemblages. A place like Guam, for instance, is a key node in the assemblage of U.S. military security in the Pacific, and assemblages of Chinese investment, and assemblages of Japanese and Korean tourism circulations, and assemblages of migration with the U.S. mainland, and a hub for surrounding islands in the FSM, etc. As Giles Deleuze and Felix Guattari (1987, p.25) (two of the founders of assemblage theory) have explained, when people speak about any entity (such as an island), it is best to describe it according to the logic of "and, and, and..." as opposed to the logic of "either/or." An island, like any entity, is an additive blend of many different disparate components that come from multiple elements and directions. It is the unique way these disparate environmental and social elements have been brought into relation with each that gives an island its distinctiveness. Furthermore, island citizens and policymakers have substantial abilities to choose how they connect to (or distance themselves from) multiple larger assemblages.

We believe that these points from assemblage theory are key for critiquing popular conceptualizations of the political rivalry between China and other powers in island spaces. They are also critical for developing a more nuanced understanding of the benefits, drawbacks, opportunities, and dangers for islands participating in foreign-orchestrated projects like China's BRI and U.S.-led security arrangements. Using a relational perspective that views influence in island spaces according to the logic of 'and, and, and...' as opposed to 'either/or' undercuts the erroneous assumption that a particular island or island state is either aligned with one country or another. With these caveats in mind, we now move on to an examination of two major political projects that have aimed to bring islands in the Pacific region into particular configurations of relations. 


\section{U.S. militarization in the western Pacific and MacArthur's 'littoral defense line'}

Geopolitical scholars, foreign policy analysts, journalists, and military strategists have frequently represented the islands and seas of the western Pacific as a political borderland between multiple world powers (Bergerson, 2016; Bohane, 2018; Davis, 2015; Meick, Ker, \& Chan, 2018; Yang, 2018; Shigematsu \& Camacho, 2010; Tobin, 2019). Over the past three centuries the islands of the region have been targets for colonial powers including Spain, Germany, the U.K., Japan, the U.S., Australia, and France. Since the end of World War II most of the islands have been under the sway of the U.S., Australia, New Zealand, or France through various free association agreements, economic linkages, circuits of migration, and - in some cases - the continuation of outright colonial rule by distant metropoles. One important aspect of these multiple political arrangements has been the military dominance in the region of the United States and its allies. Many of the military strategies for maintaining U.S. military dominance in the Pacific have centered around the 'island chain' doctrine which aims to limit the influence of Asian powers in the Pacific.

Popularized by the U.S. general Douglas MacArthur in 1951, the island chain strategy was promoted in response to the military vulnerability the U.S. experienced in the Pacific at the outset of World War II. Prior to the war, the U.S. attempted to maintain connections to Asia via an east-west string of colonial possessions in Hawai'i, Guam, and the Philippines. These were all effectively attacked (Pearl Harbor) or quickly overrun (Guam and the Philippines) by Imperial Japan in the early days of the Pacific war. MacArthur and other U.S. strategists were determined to not allow this to happen again and devised the 'island chain' strategy to effectively push the defensive border of the United States to islands on the doorstep of Asia.

The island chain strategy replaced the thin U.S.-controlled east-west linkage between North America and Asia with a set of north-south running 'chains' meant to completely block any penetration into the Pacific by an Asian power (with both China and the Soviet Union being the countries U.S. strategists were most concerned with 'containing'). The island chain strategy is predicated on the U.S. maintaining complete military control over all islands in the 'first island chain' which runs from mainland Japan, through the Ryukyu Archipelago (Okinawa), to Taiwan, Luzon and Palawan in the Philippines, and down to Borneo on its southern end (see the red lines in Figure 1). The 'second island chain' starts from Honshu and goes south through the Japanese administered Bonin Islands, and then the U.S.-affiliated Northern Mariana Islands, Guam, Yap, and Palau. According to several recent U.S. strategic doctrines, the U.S. assumes that by holding these islands it can contain the Chinese military to a 'battlespace' around the first island chain, while holding the second island chain to ensure freedom of U.S. movement and 'sea lanes of communication' (SLOCs) to supply operations within that battlespace (Hammes, 2012; Krepinevich, 2015). These strategists also note that U.S. control of these chains enables the U.S. to potentially interdict shipping coming or going from China's east coast and is a powerful source of leverage in any conflict. In order for these strategies to work, however, all of these islands must remain firmly under the political sway of the U.S. or its allies. As MacArthur (1965 [1951]) put it, “The holding of this littoral defense line in the western Pacific is entirely dependent upon holding all segments thereof; for any major breach of that line by an unfriendly power would render vulnerable to determined attack every other major segment." 


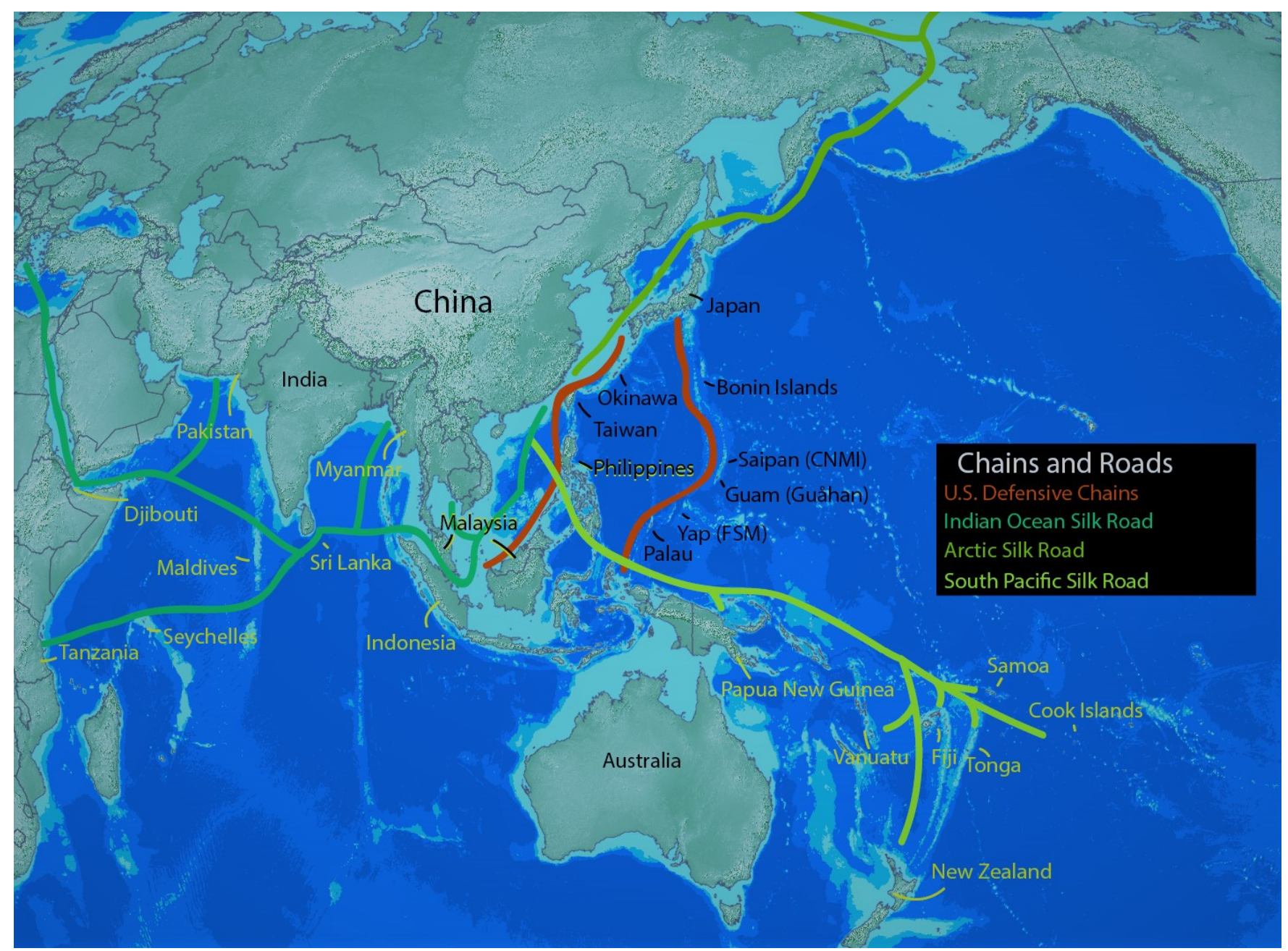

Figure 1: New Silk Roads and Defensive Chains. Islands and countries labeled in black font are places imagined to be in U.S. defensive chains. Countries listed in yellow font have signed a memorandum of understanding (MOU) to participate in the Belt Road Initiative (BRI) as of April 2019. Malaysia and the Philippines are labeled with black and yellow type because they are both part of the defensive chains and have signed BRI MOUs. Map by the authors.

This military strategy employs a potent geographical imagination that has influenced how the U.S. has engaged in these islands throughout the past 70 years. U.S.-based government officials, strategists, and scholars have frequently represented these islands of the western Pacific as if the primary function of the islands themselves (and the people on them) is to be 'links' in this U.S.-orchestrated defensive chain (Bergerson, 2016): Guam becomes America's 'tip-of-thespear' pointed at Asia, while Okinawa becomes 'the keystone of the Pacific'. In accordance with this geographical imagination, U.S. officials have consistently tried to maintain political control and military access to the islands of the first and second chains. Making sure that these islands fulfill this U.S. coordinated mission, however, has had dramatic social, economic, and environmental impacts on the islands and islanders themselves (Davis, 2015). Whether it has been the long history of U.S. support for an independent Taiwan, the denial of political selfdetermination for Guam, the maintenance of large numbers of U.S. bases and troops in Okinawa, the U.S. dictated 30-year prohibition on foreign direct investment during the years of the Pacific Trust Territory in Micronesia, the damaging effects of U.S. military training and 
weapons testing across the region, or the signing of free association agreements with Palau and the Federated States of Micronesia that allow the U.S. military unfettered access to their islands and sea spaces (and 'strategic denial' to other militaries), the U.S. has primarily acted towards these islands in ways that keep them politically, socially, and economically tied to the U.S. (or their dependable allies) as well as accessible to its military (Davis, 2015; Hanlon, 1998; Lutz, 2009; Shigematsu \& Camacho, 2010; Vine 2019).

\section{Ropes for tying up the dragon or nodes in the $21^{\text {st }}$ Century Maritime Silk Road? China's growing engagement in the island Pacific}

From the perspective of military planners and strategists in China, the island groups of the western Pacific are also viewed as U.S.-made 'chains'. Of course, they are viewed less as 'defensive chains' than as arcs of containment and ropes of potential economic strangulation (Hammes, 2012; Krepinevich, 2015). As Zhaolun Ding, an official with the Chinese People's Liberation Army (PLA), put it, the U.S. island chain doctrine makes the islands of the western Pacific into "ropes for tying up the huge dragon of China" (qtd. in Erickson \& Wuthnow, 2016, p.11). They are also sites from which commerce and energy supplies into and out of China's eastern seaboard can be threatened and cut off. There is therefore an impetus to find ways to counter the threat that emanates from these islands, as well as to work out ways to circumvent this potentially hostile assemblage of militarized islands.

China has been pursuing several island-centered strategies to counter this U.S.-led doctrine of using these islands for containment. First and foremost is China's insistence on politically reintegrating Taiwan into China. While U.S. planners since World War II have viewed Taiwan as a crucial anchor to its island chain strategy, the Chinese government has articulated quite clearly that it sees Taiwan as integral part of the PRC and that unifying the country is one of its top security goals (Erickson \& Wuthnow, 2016; Yang, 2011). Second, the Chinese government has attempted to gain more military control over the seas between the mainland and the 'first island chain' through increasing its military's technological capabilities, more forcefully claiming sovereignty over disputed islands, and constructing artificial islands in the South China Sea (Carroll, 2017; Fravel \& Twomey, 2015; Panda, 2018; Stavridis, 2017). Third, through the Belt Road Initiative, China is building infrastructure projects across Central Asia, Southeast Asia, South Asia, and the Indian Ocean region that provide a 'back door' for trade that avoids the blockade threat posed by U.S. military dominance in the island chains off its eastern seaboard. Fourth, Chinese diplomatic initiatives, investments, and tourism circulations have increased interactions directly between China and the islands of the first and second island chains - much to the chagrin of security analysts in the U.S. and their Pacific allies (Bohane, 2018a; Matelski, 2016). While the first two strategies have been written about at great length, we focus here on the latter two strategies and the environmental, political, and social effects on the islands involved.

As noted in the introduction, the Belt and Road Initiative (BRI) began as a series of railways and ports proposed by Chinese President Xi Jinping in 2013 to better connect China to countries in Europe, Africa, and Asia. It has since grown to include other geographic regions such as the island Pacific, the Arctic, and Latin America; and it has also expanded conceptually to include 'soft infrastructure' like the development of bilateral agreements and greater people- 
to-people contact between China and other countries. Countries that have signed agreements to participate in the initiative frequently rely on loans from Chinese-led banks such as the Asian International Infrastructure Bank (AIIB) to complete projects. Islands in the Indian and Pacific Ocean regions have been attracted to the BRI-even though the loans can strain existing debt burdens - since it offers an opportunity for low income countries to work alongside China to build critical infrastructure that could increase economic development. Typically, the BRI projects are designed according to the model used for economic and infrastructure development within China. Ideally, the AIIB loans are used to develop infrastructure in island states which raises the value of the surrounding land. This increase in land value (and the accompanying urbanization) then generates the funds necessary to pay back the loan principle and interest, with a surplus left over for government operations and further development (Mathews, 2019).

Many commentators, however, have viewed the BRI in islands not according to the Chinese-promoted economic perspective of mutual benefit through debt-financed development as much as through a geopolitical perspective that sees the BRI loans as a ploy to flip ownership and sovereign control of valuable land and infrastructure. Specifically, there is widespread concern the Chinese-backed loans are a 'debt trap' designed to create debt that island governments will be unable to pay back. Once island governments default, the Chinese government and Chinese firms will take ownership and control over the ports or other infrastructure. Many have pointed to Sri Lanka's experience of defaulting on loans (and then having to hand over a 99-year lease to the Hambantota Port to Chinese interests) as a prime example of debt-trapping (Abi-Habib, 2018). These concerns over debt are one reason why countries such as Malaysia have backed away from greater engagement with the BRI, and why other countries have been cautious about the project.

That said, there are several reasons why island states are interested in participating in the BRI. First, it is an available source of funds for development projects that come with fewer strings attached (such as 'structural adjustment' directives) than loans from other multilateral lenders like the World Bank, IMF, and Asian Development Bank. Secondly, despite the fact that BRI building projects can cause tremendous environmental impacts (and that there are clear climate implications for a project that aims to massively expand the transportation of petroleum, minerals, and manufactured goods), the BRI does include foci on environmental conservation and climate change adaptation and resilience-two issues critically important to island governments. The BRI can be a source of funds for projects aimed at mitigating local effects of climate change, and these funds have become available at the same time as the demoralizing decision (from the perspective of many islanders) by the United States to withdraw from the Paris Agreement, a global plan to reduce the environmental impact of greenhouse gasses, pollution and other sources of environmental harm. BRI pronouncements, on the other hand, have focused on China's support for the Paris Agreement and include promises to incorporate environmental regulations within its contracts to ensure the projects create minimal harm to the environment, use safe methods of building and waste removal, protect environmental areas such as forests and fisheries, and even build environmental research centers (Hannan \& Firth, 2015). Whether BRI projects will actually live up to these lofty rhetorical claims of environmental protection and win-win economic development is, of course, an open question. However, the fact that the BRI is presented rhetorically as a project which will take climate change seriously, respect island sovereignties, provide funds quickly for much-needed projects, and not seek 
substantial neoliberal restructuring of island economies makes it an option that many island citizens and leaders find appealing.

How though does the BRI interact with older imagined constellations of island connectivity dreamed up by other world powers? Furthermore, how do island residents navigate the competing grand schemes of distant powers, which imagine their homelands to be part of larger wholes which islanders themselves have had little participation in imagining? The western Pacific - where the conduits of the South Pacific Silk Road intersect with the U.S. 'littoral defense lines'-is an illustrative region to consider this. If we look at the regional scale through cartographic representations of the BRI and defensive chains as shown in Figure 1, it is evident that the BRI can be seen as a project designed to circumvent rather than confront the U.S. defense lines of the western Pacific. In the context of Chinese fears of a sea blockade of their eastern coast, the BRI appears as an elaborate architecture to neutralize that threat. While there are multiple domestic and economic reasons for the Chinese state's embrace of the BRI (such as integrating less developed parts of western China and finding new venues for capital investment), it is also pretty clear the conduits it creates to the west and to the Indian Ocean represent 'backdoors' that bypass the East and South China Seas, which are vulnerable to foreign blockades. This is evident by looking at the geography of the land-based 'Belt' through Central Asia as well as the China-Pakistan Economic Corridor with its terminus in Gwadar on the Indian Ocean; the building of rail lines from Yunnan through Southeast Asia to Chinesefinanced port projects in Sihanoukville (Cambodia) and Kyaukpyu (Myanmar); and the intensification of political relationships and economic agreements with island states in the Indian Ocean like the Seychelles, Sri Lanka, and Comoros (CGTN, 2018; Ellis-Petersen, 2018; Kapoor \& Thant, 2018; McBride, 2015).

This west-facing orientation of the initial BRI projects is supplemented by the later, and bolder, additions of the Arctic and South Pacific Silk Roads which originate on China's eastern seaboard. As can be seen in Figure 1, even these two Silk Roads skirt many of the islands of the first and second island chains to reach outward toward Europe and Latin America. Prominent exceptions to this include Malaysia and the Philippines, the islands which are imagined to be part of the U.S. littoral defense line and which have both also signed on as partners to the BRI. The impression one gets from looking at this broad-scale geography is that the U.S. defense lines in the western Pacific have been sidestepped by the BRI-like a 10-meter fence across a 50 -meter field. The other impression this view gives is that the BRI is not about any particular bilateral relationship, but rather about creating Chinese-financed infrastructure that connects China more intensively to almost everywhere-except the U.S. and some of its staunchest allies. In short, the BRI appears less to be about confronting geopolitically hostile powers than about reducing China's dependence on these powers and building a world economy that (at least initially) circumvents these competing powers and makes them less relevant.

While these may be the global-scale geopolitical concerns driving grand schemes like the BRI and U.S. defensive strategies, we want to now focus on an example where Chinese economic influence and U.S. military strategy interweave in an island environment. Our goal is to examine not just what these projects do in particular contexts, but also to explore how processes occurring in these islands 'reflect back' and can actually shift these larger projects. 


\section{Chinese development in the second island chain: the saga of ETG in Yap}

The saga of the 'Paradise Island' development in Yap is a useful story for examining some of the varied external and internal processes affecting islands that find themselves the focus of multiple grand foreign schemes. Yap, as shown in Figure 1, is on the 'second island' chain. As noted in our introduction, Yap and the islands of the Federated States of Micronesia (FSM) have had a long history of interaction with their neighboring islands and distant imperial powers. Politically, the FSM signed a Compact of Free Association (COFA) with the U.S. in 1986 that gave the FSM formal independence but included the maintenance of strong connections with the United States. The COFA agreement-renewed in 2004 and set to run until 2023 - provides U.S. funds for FSM government programs and allows FSM citizens to live and work in the U.S. and affiliated territories (like Guam) without a visa. The agreement also stipulates that the U.S. military has access to the islands and sea spaces of the FSM and that the U.S. can refuse access to other foreign powers.

Due to a number of factors, development in the FSM over the past 70 years has been modest, especially on Yap Island, with its population of approximately 7000 people. The FSM's small population and lack of mining resources; the existence of better-connected intervening tourism opportunities (Philippines, Guam, Fiji, Saipan, Palau) between themselves and traditional tourist markets (U.S., Australia, Europe, Japan); and outmigration to Guam, Hawai'i, and the mainland U.S. have functioned to keep standards of living low. U.S. policies after World War II that disallowed foreign direct investment (even from the U.S.) in the islands for 30 years have also hindered economic integration (Hanlon, 1998).

With the emergence of the Chinese tourism market, however, the FSM (and Yap specifically) are well positioned to become a site for increased development. One important aspect of the surge in Chinese investment in the island Pacific (in the FSM, but beyond it too) is how much of it is concentrated on tourism development. In recent years, the Chinese government has been quite supportive of boosting tourism, and it is noticeable that Chinese outbound tourism is a state-supported economic and political project. For instance, Chinese government pronouncements regarding the BRI are full of references to the importance of tourism (National Development and Reform Commission \& State Oceanic Administration, 2015; National Development and Reform Commission \& State Oceanic Administration, 2017). China is now, by far, the world's largest source of international tourists - and the market is still growing. The UN World Tourism Organization notes that there were 143 million international tourist trips taken by Chinese nationals in 2017 (UNWTO, 2018). This was an increase of almost 50 million over the number in 2013. What makes this even more remarkable is that it was not until the 1990s that Chinese citizens were allowed to start travelling outside of Chinese areas, and then only to state-sanctioned Approved Destination Status (ADS) countries. Initially these included countries such as Mongolia, Russia, Malaysia, Singapore, and the Philippines. After China joined the World Trade Organization in 2001, however, Chinese travelers experienced fewer obstacles during cross-border travel, reductions in travel costs, and the removal of many safeguard policies that had directed tourism toward only a few destinations (Guo, Kim, \& Timothy, 2007).

Increasingly, the Pacific region has been an important realm for Chinese outbound tourism and these tourism initiatives have been a point-of-entry for both Chinese political and 
economic activity in the region. In 2004 the Chinese government joined the South Pacific Tourism Organization (one of the first of many Pacific multilateral organizations China would join) and by 2005 added Pacific countries such as Papua New Guinea, Samoa, and the FSM to the list of countries Chinese tourists could visit (Yang, 2011). There are a few reasons why islands in the Pacific have been among the newly targeted destinations for Chinese outbound tourism. The first obvious reason is proximity to the population centers of eastern China. A second reason is that many of these islands already have established tourist infrastructures and resources due to their hosting of tourism from other markets. Simply put, places like Guam, Saipan, Palau, and Fiji already have some of the hotels, airports, human resources, and attractions needed for tourism. To engage with the Chinese tourism market, many established tourism destinations in the Pacific only need to reorient (or expand) what they already have. This 'reorientation' may include new facilities and activities, but it may also alter the ways island attractions are themed and represented. There are, after all, important differences between western and Chinese mythologies and cultural narratives about tropical 'paradise islands' (Chan, 2006; Davis, 2005; Luo \& Grydehøj, 2017). While tourism has been considered by some academics and marketers as a predominantly westernized experience, the decades-long rise of outbound tourism from Asian countries such as Japan, South Korea, Taiwan, and now China demonstrates that contemporary tourism trends are "adding to the complexity of global human interactions and cultural transformations" (Chan, 2006, p.187).

One reason that Yap Island has become a focus of Chinese tourism investment is that it is a tropical island destination only a four-hour direct flight from the PRC gateway cities on the east coast. Political factors, however, make Yap especially appealing for Chinese tourism. Unlike nearby Guam and Saipan which are U.S. territories for the purposes of immigration, the FSM does not require Chinese citizens to get a U.S. visa to visit. Also, it is less politically problematic for PRC tourists than nearby Palau. While Palau has experienced a surge in tourists from the PRC over the past decade, its government also raised the ire of PRC officials when Palau purposely restricted incoming Chinese tourists in early 2017-and represented them as particularly socially and environmentally damaging (China Outbound Tourism Research Institute, 2017). Furthermore, the Palauan government is one of the few left in the Pacific that recognizes the independent government of Taiwan instead of Beijing. This also factored into the Beijing government's decision in 2017 to discourage PRC citizens' travel to Palau (Everington, 2017; Master, 2018).

While Yap has these geographical and political advantages, it lacks the level of tourism and transportation infrastructure as nearby Palau, Guam, and Saipan. The Chinese company Exhibition and Travel Group (ETG), however, has aimed to change this in a big way. ETGbased in Chengdu-unveiled a plan in 2012 to build the 'Paradise Island' resort in Yap. This paradise-themed complex would be centered around a 4000-room hotel and casino complex. ETG has the financial assets and construction experience to make this project a reality. ETG, whose CEO is billionaire Deng Hong, has developed high-end hotel complexes run by the British hotel giant Intercontinental, such as the Lhasa Paradise and the Jiuzhai Paradise International Convention and Resort Center. It is also creating the Long Island development in Meishan, Sichuan that promises to be not only a tourism and convention center but also an entire upperclass residential city. It also constructed the enormous New Century Global Center in Chengdu, 
which is, by floor space, the third-largest building in the world and includes an enormous indoor water park which, interestingly, is also centered around the 'paradise island' theme.

ETG's initial plan for Yap was breathtaking in its scope. The plan called for an almost complete rearrangement of the physical and social landscapes of Yap. While promising to boost the GDP of Yap over 100-fold, the plan detailed the construction of not only a massive hotel complex in the Maap area of Yap Island, but also a golf course, a large conservation area for water supply protection, a new government building, shopping areas, an upgraded dock, and an expanded airport capable of handling the envisioned 40-plus direct flights per day (Yap airport currently hosts approximately four flights per week). Most troubling for many Yapese, however, was the potential construction of what the planning documents referred to as 'Native Town' where Yapese people would reside after being displaced by the new development.

Predictably, this new megaproject in Yap has been the source of great conflict, debate, and concern among local residents as well as Yapese living off-island (Zotomayor, 2014). In interviews conducted by one of the authors in Yap in 2016 and 2017, many residents told stories of landowners and government officials accepting under-the-table payments - or signing away access to land-without the necessary consultations through formal and traditional governance structures. As with almost any kind of project of this scope (especially when done in a relatively small and traditional island society), the 'Paradise Island' project on Yap has fractured the population between people who seek the benefits of the project and those who are more concerned about the social and environmental consequences.

As of 2019, the project in Yap is not as far along as the initial plan had envisioned. According to interviews with an ETG official, tourism planners, and independent hoteliers in Yap, ETG's new plan is to start the operation with a total of 1000 rooms spaced around the island rather than in one large complex. ETG has purchased many properties around the island as well as a hotel in the center of the main town of Colonia. Several interviewees noted that some of the development has slowed because the Yap state government has been implementing stricter foreign investment laws that appear to be aimed at blocking the ETG project. Furthermore, the Yap government has also floated the idea that licenses to conduct business on the island must be renewed every year. This has concerned not only ETG's representative on the island, but other foreign businesspeople who are concerned that they could potentially invest substantial amounts of money in projects on the island and then lose their ability to operate them. Another twist that has confused the situation is that people on Yap are reporting on social media (especially though the Facebook group 'Yap's Development') that there are other Chinese companies making land deals on island. People have expressed uncertainty as to whether these other companies are acting as agents of ETG or whether they are potential competitors.

While there are local anxieties and resistance to ETG's project on Yap, the project has also generated substantial concern among U.S. military strategists and security analysts. The concerns of Western observers over the ETG plans in Yap fit into the larger framework of Western fears of Chinese influence in the region as a whole, but they strike an especially sharp chord because of Yap's imagined key position in the 'second island chain'-and the role of that imagined archipelago in U.S. security strategies and discourses (Bohane, 2016, 2018a; Frangos, 2013; Cheng, 2016; Matelski, 2016). To some, the ETG project on Yap-coupled with Chinese state diplomatic engagement and aid programs in the FSM-shows how the U.S. is "losing the Pacific" (Bohane, 2016, 2018a). Others see the tourism operation as a 'Trojan horse' of sorts 
that will lead to an eventual base for China's People's Liberation Army (Cheng, 2016). In these more suspicious narratives, the fact that these material infrastructures have connections and interoperability with Chinese networks means they can more easily be 'flipped' by Chinese interests to other (military) uses. In this view, expanded runways and docks on Yap for tourist use can just as easily serve as facilities for military planes and vessels. A Chinese military presence in Yap could then effectively block the U.S. 'sea lanes of communication' (SLOCs) into and out of the imagined 'battlespace' around the first island chain and directly threaten major U.S. bases in nearby Guam. In this light, the tourism operation is viewed not only as a potential longterm risk to the U.S. due to a slow economic or diplomatic reorientation of the island toward China. It is also seen as an immediate security risk because it establishes the infrastructure for a Chinese military presence on the second island chain - a presence which would tear asunder U.S. strategic doctrines and military plans that have been in place since the end of World War II.

\section{Conclusions: beyond spheres of influence in the island Pacific}

While these kinds of geopolitical discussions of islands in the Pacific are fairly commonplace in Western media, government policy documents, and even scholarly accounts; we find that the geographic imagination that underpins many of them is fundamentally flawed. Specifically, many authors portray influence in islands, and the political allegiance of small island states, as an either/or game. Either the FSM are loyal to the U.S., or they are loyal to China. In this view, an island-or the archipelagic country of which it is a part-is either in one mutually exclusive sphere of influence or another.

A deeper critique informed by assemblage theory, however, suggests that 'influence' in islands is something constructed out of multiple types of interactions (economic, political, cultural, etc.) that simultaneously emanate from multiple distant places-not all just from one metropole or another. In short, islands are not isolated points wholly 'captured' by this or that imperial apparatus. Political maps of the world may assign individual islands to particular states via parenthetical notes under their names - such as 'Guam (USA)' - or by coloring island territories on maps the same as nearby mainlands, or by drawing lines in the sea around collections of islands with similar political affiliations. The reality, however, is that islands (especially ones on active trade routes) have long been cosmopolitan sites that are simultaneously connected to multiple global influences (DeLanda, 2006).

The example of Yap discussed above aptly demonstrates that there are multiple (economic, political, social) influences crisscrossing and mixing. If the ETG development is built, but the COFA is renewed in 2023, in whose 'sphere of influence' exactly does Yap sit? This question can be expanded to other islands as well. What If Papua New Guinea builds a dock with Chinese money, but keeps tight political relationships with Australia? What if Niue builds a highway as part of the BRI, but keeps its free association agreement with New Zealand? What if French political sway continues in French Polynesia as Chinese investment also grows? What if Chinese tourists become the economic lifeblood of Saipan while it remains a commonwealth of the U.S.? What if Vanuatu refuses an exclusive defense agreement with Australia (as happened in early 2019), but still maintains that it is 'non-aligned' and that the government values its political and economic connections to Australia, New Zealand, and China (Bohane, 2018b; RNZ, 2019)? 
In short, influence and connectivity in the island Pacific are multivalent-both in terms of the forms they take and their points of origin. The result is that individual islands are not so much aligned exclusively in one direction or another, or toward this or that imperial power. Instead, environmental, political, and cultural interactions and influences from multiple directions accumulate and amalgamate (the logic of 'and, and, and...'). A number of political leaders from Pacific islands appear to be conscious of this and have no qualms whatsoever about developing and maintaining connections to multiple foreign powers, even ones that see each other as rivals (Wesley-Smith, 2013; Xinhua, 2018; Yang 2011). After all, even in the current context of trade wars and heated political rhetoric, the U.S. and China themselves have incredibly extensive economic interaction with each other. Why should U.S.-based analysts insist that the U.S. itself can have extensive economic relationships with China, but that the islands that sit between the U.S. and China should not?

The existence of these overlapping influences make the entire concept of neatly delineated spheres of influence analytically problematic and politically out of date. If this is true, however, why do the logics of 'either/or' allegiance and imperial rivalry continue to dominate headlines, think-tank position papers, and the proclamations of military strategists and politicians? Why is a Chinese infrastructure project in Vanuatu viewed as a threat to Australia? Why are Chinese tourists in Yap portrayed as a threat to U.S. security? One reason is simply that sensationalism and the overstatement of threats are common journalistic techniques that help stories get attention. Would the construction of a dock in Vanuatu be front page news in Sydney if it was not perceived as a national security threat? Would a tourism operation in Yap have been featured in the Wall Street Journal if it was financed by Japanese or British capital? In addition to the matter of sensationalism, however, many of the authors writing about island affairs are security analysts and military planners chiefly concerned with what Chinese influence in the region means for the security doctrines of their home countries (Bergerson, 2016; Newsham, 2018; Meick, Ker, \& Chang, 2018). Many of these authors are, by profession, predisposed to erring on the side of threat identification and may "assume, rather than demonstrate" (Wesley-Smith, qtd. in Yang, 2011, p.132) that China aims to use deeper economic connections with islands as stepping stones to eventual military involvement.

Another reason for the threat narrative is the widespread geographical imagination that assumes that any space, island or not, is ruled by one single, supreme, political sovereign of some sort or another sovereign with similar omnipotent powers to be the only 'influencer' in a given territory. As we have tried to show here-and as other geographical theorists have convincingly argued - this is not how power and influence work (Agnew, 2017; Allen, 2016; Brown, 2010). The idea that a particular island must be controlled by one powerful state or another is partly an artifact of faulty dualistic thinking in general, but it is also steeped in colonial logics and anxieties. The islands of the western Pacific have a long history of hearing that they are being colonized in order to save them from someone else's (allegedly worse) colonialism (Shigematsu \& Camacho, 2010). Once a claim is made by a foreign power, colonialism functions not only through the forced political, economic, and cultural articulation with a given imperial assemblage, but by precluding a place's ability to articulate with others or even with resources within their own locality (through land seizure, colonial political apparatuses, the destruction of local livelihood practices and knowledges, etc.). In U.S. territories in Micronesia, for instance, the U.S. has a long history (and present) of separating U.S.-affiliated areas from Asia and other 
island nations through blocking foreign investment, controlling where shipping and trade can come from (as through the U.S. Jones Act), and federalizing migration and visa controls (Frain, 2016; Hanlon, 1998; Loyd, Mitchell-Eaton, \& Mountz, 2016).

In many respects, the Western anxiety over Chinese investment and diplomatic attention is a concern over islands having options. As noted above, islands are not intrinsically part of any larger constellation/chain/belt/road. When they have options, they can be connected to multiple assemblages at once. It is perhaps understandable that a change in context that allows island policymakers and residents to have choices would produce anxiety in Western capitals that have long been used to the idea that they have carved up the Pacific into agreed-upon, mutually exclusive realms of solo (post)colonial responsibility/dominance (the U.S. in Micronesia, France in its overseas 'collectivities,' Australia in Melanesia, etc.). After all, having more local agency could very well destabilize all sorts of grand schemes, and also make island leaders question whether they still have to put up with the many negatives that have come with reliance on one foreign power.

If we look at China's involvement in the region from the point of view of islands-rather than from the perspective of nervous Western security sources-China's engagement in the Pacific represents not so much a switch of colonialisms as something which can be used as leverage to undermine colonial relationships. This may not be China's reason for engaging in the region, but it can have that affect. This is not to say that engagement with China poses no risks to islands in the Pacific. As the short description of the Paradise Island development in Yap details, the environmental, social, political, and cultural impacts of Chinese-led large-scale developments are anything but benign. Furthermore, as examples from Sri Lanka, Myanmar, Fiji, Niue, and other BRI countries show, Chinese projects-as with development projects conducted by any outside power-have the potential to upend island societies with heavy debt burdens, unfinished projects, corrupt practices, environmental damage, loss of access to important resources, increased income inequality, and the exacerbation of local social schisms (Blanchard \& Flint, 2017; Hannan \& Firth, 2015; Mathews, 2019; McBride, 2015; Reid, 2019). Nobody should be blind to the dangers of being part of someone else's 'road', any less than to the dangers of remaining in someone else's 'chain'. Still, it is misleading to portray every project that originates in China as representing the island 'flipping' into a state of Chinese allegiance. There is no 'line' in the ocean, with 'China's islands' on one side and 'U.S. islands' on the other.

To understand how the larger schemes of distant powers play out in island landscapes, island studies researchers would do well to maintain an island-centered focus that stands in the islands and looks outward toward the surrounding powerful states, rather than vice versa (Hereniko \& Wilson, 1999). From this point of view, China's involvement in Pacific island life is an additional influence in the region, not a replacement. It changes the field of potentialities in which islands are situated-i.e. the milieu of potential options for linkage and interaction. While there are larger political economic trends and government plans that affect the development options in small island states, people on these islands also exert their own agency in ways which not only alter local projects, but also reflect back to these broader scales and can alter grand regional political and economic schemes. The example of Yap-where local opposition to the Paradise Island project has significantly delayed it and scaled it back-is an important reminder that while islands are affected by the grand schemes of continental powers, they are charting their own courses through them as well. 


\section{Acknowledgements}

The authors would like to thank the interview respondents that made this research possible. We would also like to thank the Keene State College School of Sciences, Sustainability and Health for research support that led to this article. We would also like to thank those who have reviewed and commented on the paper for their efforts and valuable insights, which were instrumental in improving this paper.

\section{References}

Abi-Habib, M (2018, June 25) How China got Sri Lanka to cough up a port. The New York Times. Retrieved from https://www.nytimes.com/2018/06/25/world/asia/china-srilanka-port.html

Agnew, J. (2017). Globalization and sovereignty: Beyond the territorial trap. $2^{\text {nd }}$ ed. New York: Rowman \& Littlefield.

Allen, J. (2016). Topologies of power: Beyond territory and networks. Routledge: New York.

Allen, J. (2011). Topological twists: Power's shifting geographies. Dialogues in Human Geography, 1, 283-298. https://doi.org/10.1177/2043820611421546

Anderson, B., Keanes, M., McFarlane, C., \& Swanton, D. (2012). On assemblages and geography. Dialogues in Human Geography, 2, 171-189. https://doi.org/10.1177/2043820612449261

Baldacchino, G. (2006). Islands, island studies, island studies journal. Island Studies Journal, 1(1), 3-18.

Barry, A. (2006). Technological zones. European Journal of Social Theory, 9(2), 239-253.

Benitez-Rojo, A. (1997) The repeating island: The Caribbean and the postmodern perspective. Durham: Duke University Press.

Bevacqua, M. (2017). Guam through the eyes of a child: The N. Korean missile conflict. The Guam Guide. Retrieved from http://theguamguide.com/guam-through-the-eyes-of-achild-the-U.S.-north-korean-missile-conflict-in-perspective/

Blanchard, J. (2018). China's Maritime Silk Road Initiative and South Asia: A political economic analysis of its purposes, perils, and promise. London: Palgrave. https://doi.org/10.1007/978981-10-5239-2 1

Blanchard, J., \& Flint, C. (2017). The geopolitics of China's Maritime Silk Road initiative. Geopolitics, 22(2), 223-245. https://doi.org/10.1080/14650045.2017.1291503

Bohane, B. (2018a). The United States is Losing the Pacific. East-West Center. Retrieved from https://www.eastwestcenter.org/system/tdf/private/apb414 1.pdf?file=1\&type=node\&i $\underline{\mathrm{d}=36582}$

Bohane, B. (2018b, June 13) South Pacific nation shrugs off worries on China's influence. The New York Times. Retrieved from https://www.nytimes.com/2018/06/13/world/asia/vanuatu-china-wharf.html

Bohane, B. (2016, June 2). U.S. stresses 'unique' Pacific islands links, as China's regional footprint grows. ABC News. Retrieved from http://www.abc.net.au/news/2016-0601/U.S.-stresses-unique-pacific-islands-links/7466368

Brown, W. (2010). Walled states, waning sovereignty. Cambridge: MIT Press. 
Carroll, C. (2017, June 9) Protecting the South China Sea. Foreign Policy. Retrieved from https://www.foreignaffairs.com/articles/china/2017-06-09/protecting-south-china-sea

CGTN (2018, September 1) China, Comoros to promote ties to higher level. CGTN. Retrieved from https://news.cgtn.com/news/3d3d514e3441544f79457a6333566d54/share p.html

Chan, Y. (2006). Coming of age of the Chinese tourists: The emergence of non-Western tourism and host-guest interactions in Vietnam's border tourism. Tourist Studies, 6(3), 187213. https://doi.org/10.1177/1468797607076671

Chandler, D., \& Pugh, J. (2019). Islands of relationality and resilience: The shifting stakes of the Anthropocene. Area. Epub ahead of print. https://doi.org/10.1111/area.12459

Cheng, D. (2016). Countering Chinese inroads into Micronesia. Heritage Foundation. Retrieved from https://www.heritage.org/asia/report/countering-chinese-inroads-micronesia

Chua, C., Danyluk, M., Cowen, D., \& Khalili, L. (2018). Introduction: Turbulent circulation: Building a critical engagement with logistics. Environment and Planning D: Society and Space, 36(4), 617-629. https://doi.org/10.1177/0263775818783101

Cowen, D. (2014). The deadly life of logistics: Mapping violence in global trade. University of Minnesota Press: Minneapolis. https://doi.org/10.5749/minnesota/9780816680870.001.0001

Davis, S. (2017). Apparatuses of occupation: Translocal social movements, states and the archipelagic spatialities of power. Transactions of the Institute of British Geographers, 42(1), 110-122. https://doi.org/10.1111/tran.12152

Davis, S. (2015). The empires' edge: Militarization resistance and transcending hegemony in the Pacific. Athens, GA: University of Georgia Press.

Davis, S. (2005) Representing place: 'Deserted isles' and the reproduction of Bikini Atoll. Annals of the Association of American Geographers, 95, 607-625. https://doi.org/10.1111/j.14678306.2005.00477.x

DeLanda, M. (2006). A new philosophy of society: Assemblage theory and social complexity. New York: A\&C Black.

Deleuze, G. (1988) Foucault. Minneapolis: University of Minnesota Press.

Deleuze, G., \& Guattari, F. (1987). A thousand plateaus: Capitalism and schizophrenia. Minneapolis: University of Minnesota Press.

DeLoughrey, E. (2007). Routes and roots: Navigating Caribbean and Pacific Island literatures. Honolulu: University of Hawaii Press. https://doi.org/10.1515/9780824864187

Dewsbury, J. (2011). The Deleuze-Guattarian assemblage: Plastic habits. Area, 43, 148-153. https://doi.org/10.1111/j.1475-4762.2011.01006.x

Diaz, V. (2011). Voyaging for anti-colonial recovery: Austronesian seafaring, archipelagic rethinking, and the re-mapping of indigeneity. Pacific Asia Inquiry, 2, 21-32.

Dittmer, J. (2018) The state, all at sea: Interoperability and the Global Network of Navies. Environment and Planning C. https://doi.org/10.1177/2399654418812469

Dittmer, J. (2014). Geopolitical assemblages and complexity. Progress in Human Geography, 38, 385-401. https://doi.org/10.1177/0309132513501405

Ellis-Petersen, H. (2018, July 31). 'No Cambodia left': How Chinese money is changing Sihanoukville. The Guardian. Retrieved from https://www.theguardian.com/cities/2018/jul/31/no-cambodia-left-chinese-moneychanging-sihanoukville 
Erickson, A., \& Wuthnow, J. (2016). Barriers, springboards and benchmarks: China conceptualizes the Pacific 'island chains'. The China Quarterly, 225, 1-22. https://doi.org/10.1017/s0305741016000011

Everington, K. (2017, November 23). China bans tour groups to Vatican, Palau to isolate Taiwan. Taiwan News. Retrieved from

https://www.taiwannews.com.tw/en/news/3304777

Featherstone, D. (2011). On assemblage and articulation. Area, 43(2), 139-142.

Frain, S. (2016). Resisting political colonization and American militarization in the Marianas Archipelago. AlterNative, 12, 298-315. https://doi.org/10.20507/alternative.2016.12.3.7

Frangos, A. (2013, March 9). Is Yap ready for the world? The Wall Street Journal. Retrieved from https://www.wsj.com/articles/SB10001424127887324712504578131864269855132

Fravel, M., \& Twomey, C. (2015) Projecting strategy: The myth of Chinese counterintervention. The Washington Quarterly, 37(4), 171-187. https://doi.org/10.1080/0163660x.2014.1002164

Grydehøj, A., \& Casagrande, M. (2019). Islands of connectivity: Archipelago relationality and transport infrastructure in Venice Lagoon. Area. Epub ahead of print. https://doi.org/10.1111/area.12529

Grydehøj, A., Nadarajah, Y., \& Markussen, U. (2019). Islands of indigeneity: Cultural distinction, Indigenous territory and island spatiality. Area. Epub ahead of print. https://doi.org/10.1111/area.12520

Grydehøj, A., Heim, O., \& Zhang, H. (2017). Islands of China and the Sinophone world. Island Studies Journal, 12(2), 3-7. https://doi.org/10.24043/isj.41

Guo, Y., Kim, S., \& Timothy, D. (2007). Development characteristics and implications of mainland Chinese outbound tourism. Asia Pacific Journal of Tourism Research, 12(4), 313332. https://doi.org/10.1080/10941660701760995

Hammes, T. (2012). Offshore control: A proposed strategy for an unlikely conflict. Strategic Forum 278. Washington, D.C.: National Defense University Press. https://doi.org/10.21236/ada577602

Hanlon, D. (1998). Remaking Micronesia: Discourses over development in a Pacific territory, 19441982. Honolulu: University of Hawaii Press. https://doi.org/10.1515/9780824864118

Hannan, K., \& Firth, S. (2015). Trading with the Dragon: Chinese trade, investment and development assistance in the Pacific Islands. Journal of Contemporary China, 24(95), 865882. https://doi.org/10.1080/10670564.2015.1013377

Hau'ofa, E. (1994). Our sea of islands. The Contemporary Pacific, 6(1) 148-161.

Hayward, P. (2012) Aquapelagos and aquapelagic assemblages. Shima, 6(1), 1-11.

Hereniko, V., \& Wilson, R. (1999). Inside out: Literature, cultural politics, and identity in the new Pacific. New York: Rowman \& Littlefield. https://doi.org/10.2307/40155615

Hong, G. (2019). Islands of enclavisation: Eco-cultural island tourism and the relational geography of near-shore islands. Area. Epub ahead of print. https://doi.org/10.1111/area.12521

Hong, G. (2017). Locating Zhuhai between land and sea: A relational production of Zhuhai, China, as an island city. Island Studies Journal, 12(2), 7-24. https://doi.org/10.24043/isj.16

Immerwahr, D. (2019). How to hide an empire: A history of the Greater United States. New York: Farrar, Straus and Giroux. 
Kapoor, K., \& Thant, A. (2018, August 2). Exclusive: Myanmar scales back Chinese-backed port project due to debt fears. Retrieved from https://www.reuters.com/article/U.S.myanmar-china-port-exclusive/exclusive-myanmar-scales-back-chinese-backed-portproject-due-to-debt-fears-official-idUSKBN1KN106

Kearns, R., \& Collins, D. (2016). Aotearoa's archipelago: Re-imagining New Zealand's island geographies. New Zealand Geographer, 72(3), 165-168. https://doi.org/10.1111/nzg.12140

Krepinevich, A. (2015). How to deter China: The case for archipelagic defense. Foreign Affairs, 94, 1-6.

Legg, S. (2011). Assemblage/apparatus: Using Deleuze and Foucault. Area, 43, 128-133. https://doi.org/10.1111/j.1475-4762.2011.01010.x

Lingenfelter, S., (1975). Yap: Political leadership and culture change in an island society. Honolulu: University of Hawaii Press.

Loyd, J., Mitchell-Eaton, E., \& Mountz, A. (2016). The militarization of islands and migration: Tracing human mobility through U.S. bases in the Caribbean and the Pacific. Political Geography, 53, 65-75. https://doi.org/10.1016/j.polgeo.2015.11.006

Luo, B., \& Grydehøj, A. (2017). Sacred islands and island symbolism in Ancient and Imperial China: an exercise in decolonial island studies. Island Studies Journal, 12(2), 25-45. https://doi.org/10.24043/isj.19

Lutz, C. (2009). The bases of empire: The global struggle against U.S. military posts. New York: NYU Press.

MacArthur, D. (1965). A soldier speaks: Public papers and speeches of General of the Army, Douglas MacArthur. Santa Barbara: Praeger.

Matelski, T. (2016, February 19) America's Micronesia problem. The Diplomat. Retrieved from https://thediplomat.com/2016/02/americas-micronesia-problem/

Mathews, J. A. (2019). China's long-term trade and currency goals: The Belt \& Road Initiative. Asia-Pacific Journal-Japan Focus, 17(1).

Master, F. (2018, August 19). Empty hotels, idle boats: What happens when a Pacific island upsets China. Reuters. Retrieved from https://www.reuters.com/article/U.S.-pacificchina-palau-insight-idUSKBN1L4036

McBride, J. (2005) Building the New Silk Road. Council on Foreign Relations. Retrieved from https://www.files.ethz.ch/isn/190994/The\%20New\%20Silk\%20Road\%20_ \%20Council\%20on\%20Foreign\%20Relations.pdf

McConnell, F., \& Dittmer, J. (2018). Liminality and the diplomacy of the British Overseas Territories: An assemblage approach. Environment \& Planning D, 36(1), 139-158. https://doi.org/10.1177/0263775817733479

McElroy, J. L., \& Bai, W. (2008). The political economy of China's incursion into the Caribbean and Pacific. Island Studies Journal, 3(2), 225-246.

McFarlane, C. (2009). Translocal assemblages: Space power and social movements. Geoforum, 40, 561-567. https://doi.org/10.1016/j.geoforum.2009.05.003

Meick, E., Ker, M., \& Chan, H., (2018). China's engagement in the Pacific Islands: Implications for the United States. U.S.-China Economic and Security Review Commission staff research report. Retrieved from https://www.uscc.gov/sites/default/files/Research/ChinaPacific\%20Islands\%20Staff\%20Report.pdf 
Müller, M. (2015). Assemblages and actor-networks: Rethinking socio-material power politics and space. Geography Compass, 9, 27-41. https://doi.org/10.1111/gec3.12192

Na'puti, T. (2019) Archipelagic rhetoric: Remapping the Marianas and challenging militarization from 'A Stirring Place'. Communication and Critical/Cultural Studies, 16(1), 4-25. https://doi.org/10.1080/14791420.2019.1572905

Na'puti, T., \& Bevacqua, M. (2015) Militarization and resistance from Guåhan: Protecting and defending Pagat. American Quarterly, 67, 837-858. https://doi.org/10.1353/aq.2015.0040

Newsham, G. (2018). Mariana Islands - U.S. military strategy 'on hold'. East-West Center. Retrieved

from https://www.eastwestcenter.org/system/tdf/private/apb415 0.pdf?file=1\&type $=$ node\&i $\underline{\mathrm{d}=36583}$

Nolan, P. (2013). Imperial archipelagos: China, western colonialism and the law of the sea. New Left Review, 80, 77-95.

Panda, A. (2018). South China Sea: U.S. destroyer conducts freedom of navigation operations near Scarborough Shoal. The Diplomat. Retrieved from https://thediplomat.com/2018/01/south-china-sea-U.S.-destroyer-conducts-freedomof-navigation-operations-near-scarborough-shoal/

Peters, K., Steinberg, P., \& Stratford, E. (2018). Territory beyond terra. New York: Rowman \& Littlefield.

Powles, M. (2015). China and the Pacific: The view from Oceania. New Zealand International Review, 40(3), 25-28.

Pugh, J. (2018). Relationality and island studies in the Anthropocene. Island Studies Journal, 13(2), 93-110. https://doi.org/10.24043/isj.48

Pugh, J. (2016). The relational turn in island geographies: bringing together island, sea and ship relations and the case of the Landship. Social \& Cultural Geography, 17(8), 1040-1059. https://doi.org/10.1080/14649365.2016.1147064

Pugh, J. (2013). Island movements: thinking with the archipelago. Island Studies Journal, 8(1), 9-24.

Qiu, S., Yue, W., Zhang, H., \& Qi, J. (2017). Island ecosystem services value, land-use change, and the National New Area Policy in Zhoushan Archipelago, China. Island Studies Journal, 12(2), 177-198. https://doi.org/10.24043/isj.20

Reid, M. (2019, February 7). Massive resort desecrates Fiji island jewel. Newsroom. Retrieved from https://www.newsroom.co.nz/2019/02/06/429704/fiji-resort-environmentaldestruction?preview $=1 \& \mathrm{fbclid}=$ IwAR2pARp9BpbwnFZvNycGvpbY e4ZRCl3uPX80 Ma8K2S1hiecJg2uRb8tKUM

RNZ (2019, January 15). Vanuatu not keen on Australian security treaty. Radio New Zealand. Retrieved from https://www.radionz.co.nz/international/pacificnews/380167/vanuatu-not-keen-on-australian-security-treaty

Shell, M. (2014). Islandology: Geography, rhetoric, politics. Palo Alto: Stanford University Press.

Shigematsu, S., \& Camacho, K. (2010). Militarized currents: Toward a decolonized future in Asia and the Pacific. Minneapolis: University of Minnesota Press. https://doi.org/10.5749/minnesota/9780816665051.001.0001

Stavridis, J. (2017). Sea power: The history and geopolitics of the world's oceans. London: Penguin.

Steinberg, P., \& Peters, K. (2019). The ocean in excess: Towards a more-than-wet ontology. Dialogues in Human Geography. https://doi.org/10.1177/2043820619872886 
Stratford, E., Baldacchino, G., McMahon, E., Farbotko, C., \& Harwood, A. (2011). Envisioning the archipelago. Island Studies Journal, 6(2) 113-130.

Suokas, J. (2017, June 21). China adds Arctic sea route to its Silk Road plan. GB Times. Retrieved from https://gbtimes.com/china-adds-arctic-sea-route-its-silk-road-plan

Tobin, M. (2019, January 19) U.S.-China battle for dominance extends across Pacific, above and below the sea. South China Morning Post. Retrieved from https://www.scmp.com/week-asia/geopolitics/article/2182752/us-china-battledominance-extends-across-pacific-above-and

UNWTO (2018). China: Country-specific: Basic indicators (Compendium) 2013 - 2017. UNWTO. Retrieved from https://www.eunwto.org/doi/abs/10.5555/unwtotfb0156010020132017201812

Vine, D. (2015). Base nation: How U.S. military bases abroad harm America and the world. New York: Metropolitan Books.

National Development and Reform Commission (2015). Vision and actions on jointly building Silk Road Economic Belt and 21st-Century Maritime Silk Road. National Development and Reform Commission, Ministry of Foreign Affairs, and Ministry of Commerce of the People's Republic of China, with State Council authorization. Retrieved from http://en.ndrc.gov.cn/newsrelease/201503/t20150330 669367.html

National Development and Reform Commission \& State Oceanic Administration (2017). Vision for Maritime Cooperation under the Belt and Road Initiative. National Development and Reform Commission \& State Oceanic Administration. Retrieved from http://www.yidaiyilu.gov.cn/wcm.files/upload/CMSydylgw/201706/201706200153032.pdf

Watson, I., \& Pandey, C. (2015). Environmental security in the Asia-Pacific. New York: Palgrave.

Wroe, D. (2018, April 13). Trouble in paradise: China has been carefully building its influence across the Pacific. Sydney Morning Herald. Retrieved from https://www.smh.com.au/politics/federal/trouble-in-paradise-20180413-p4z9dj.html

Xinhua News Agency (2018). Xi meets leaders of Pacific island nations to further BRI cooperation. Xinhua. Retrieved from http://www.xinhuanet.com/english/2018$11 / 17 / \mathrm{c} 137612228 . \mathrm{htm}$

Yang, J. (2011). The Pacific islands in China's grand strategy: Small states, big games. New York: Springer.

Zotomayor, L. (2014). Mega-casino resort project reportedly 'still on the table' in Yap. Pacific Islands Report. Retrieved from http://www.pireport.org/articles/2014/06/05/megacasino-resort-project-reportedly-\%E2\%80\%98still-table $\%$ E2\%80\%99-yap 
Sasha Davis, Lexi A. Munger, E Hannah J. Legacy 